\title{
KREATIVITAS GURU PAI DALAM MENINGKATKAN HAFALAN AL-QUR'AN JUZ 30 MELALUI METODE WAHDAH PADA SISWA KELAS VI SDN 35 NUNGGA KOTA BIMA
}

\author{
Suratman \\ Sekolah Dasar Negeri 35 Nungga Kota Bima \\ Email: suratmanimm27@gmail.com
}

\begin{abstract}
Abstrak
Penelitian ini terfokus pada kreativitas guru PAI dalam meningkatkan hafalan Al-Qur'an siswa pada juz 30 melalui metode wahdah di SDN 35 Nungga Kota Bima. Metode wahdah adalah merupakan metode menghafal Al-Qur"ean dengan cara satu persatu terhadap ayat yang hendak dihafalnya secara berulang-ulang. Tidak sedikit dari siswa yang mengeluhkan tentang sulitnya menghafal Al-Qur'an, itu disebabkan banyaknya siswa yang belum mengetahui tentang metode-metode yang dapat digunakan dalam menghafal al-Qur"an. Untuk menjawab persoalan tersebut maka metodologi dalam penelitian ini adalah penelitian lapangan (Field Research) yakni menggunakan pendekatan deskriptif kualitatif dengan teknik data melalui observasi dan wawancara. Metode analisis data menggunakan teknik analisis deskriptif. Temuan penelitian ini menunjukkan bahwa guru PAI di SDN 35 Nunggi Kota Bima telah menerapkan menerapkan metode wahdah dalam meningkatkan hafalannya siswa . sehingga dapat disimpulkan setelah guru menerapkan metode wahdah dalam menghafal Al-Qur'an maka siswa mampu menyelesaikan hafalannya dengan waktu yang relatif singkat dan standar.
\end{abstract}

Kata Kunci: Kreativitas Guru, Al-Qur'an, Metode Wahdah

\section{PENDAHULUAN}

l-Qur'an adalah firman Allah yang tidak terdapat kebatilan di
dalamnya, dan Al-Qur'an adalah mu'jizat terbesar dan kekal
bagi Rasulullah SAW. Allah SWT sudah memerintahkan agar menjaganya dari perubahan dan penggantian ( Abdurrab Nawabudin, 1991). Allah swt berfirman :

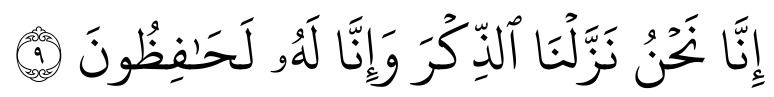

Artinya : Sesungguhnya Kami-lah yang menurunkan AlQur'an, dan Sesungguhnya Kami benar-benar memeliharanya." (Q.S. Al-Hijr : 9) (Departemen Agama RI, 2006). 
Pemerintah Kota Bima dalam Hal ini Baznaz dengan berkerja sama dengan Sekolah Tinggi Ilmu Qur'an (STIQ) Bima dalam satu semestes selama 4 bulan pada tahun ajaran pertama sudah berkomitmen untuk mengaktualisasikan Metode Pembelajaran Bagdady pada Sekolah Dasar se-Kota Bima yang di ambil sebagai bahan penerapan Metode Bagdady ini adalah Kelas V SD dengan menerapkan pembelajaran 1 jam terakhir dalam 4 kali pertemuan dalam satu pekan, maka jika agenda baznaz ini tidak kita jemput dengan melakukan penguatan dengan mengulang kembali hafalan anak-anak yang telah di terapkan maka hafalan mereka akan hilang, maka dari itu sebagai Guru Agama Islam perlu dan penting untuk mengulang-ngulang kembali dengan cara menerapkan metode Wahdah dalam penguatan hafalan anak-anak.

Menghafal Al-Qur'an dapat dikatakan sebagai langkah awal dalam suatu proses penelitian yang dilakukan oleh para penghafal AlQur'an dalam memahami kandungan ilmu-ilmu Al-Qur'an, tentunya setelah proses dasar membaca Al-Qur'an dengan baik dan benar, akan tetapi ada juga yang sebaliknya, yaitu belajar isi kandungan Al-Qur'an terlebih dahulu kemudian menghafalnya (Ahsin W, 2000). Progam pendidikan menghafal Al-Qur'an adala Program menghafal Al-Qur'an dengan mutqin (Hafalan yang kuat) terhadap lafadz-lafadz Al-Qur'an dan menghafal makna-maknanya dengan kuat yang memudahkan untuk menghadirkannya setiap menghadapi berbagai masalah kehidupan, karena Al-Qur'an senantiasa ada dan hidup di dalam hati sepanjang waktu, sehingga memudahkan untuk menerapkan dan mengamalkannya (Khalid bin Abdul Karim Al-Lahim, 2008).

Sudah dimaklumi bersama dan sudah sangat jelas, bahwa menghafal Al-Qur'an bukanlah tugas yang mudah, sederhana, serta dapat dilakukan kebanyakan orang tanpa meluangkan waktu khusus, kesungguhan mengerahkan kemampuan dan keseriusan (Raghib AsSirjani, 2007). karena menghafal Al-Qur'an merupakan tugas yang sangat agung dan besar. Tidak ada yang sanggup yang melakukannya selain Ulul 'Azmi, yakni orang- orang yang bertekad kuat dan bulat serta keinginan membaca. Kiranya tidak berlebihan jika dikatakan bahwa menghafal Al-Qur'an itu berat dan melelahkan. Hal ini dikarenakan 
banyak problematika yang harus dihadapi para penghafal Al-Qur'an untuk mencapai derajat yang tinggi di sisi Allah SWT. Mulai dari pengembangan minat, penciptaan lingkungan, pembagian waktu sampai kepada metode menghafal itu sendiri (Ahsin W, 2000).

Para penghafal Al-Qur'an juga banyak yang mengeluh bahwa menghafal itu susah. Hal ini disebabkan karena adanya gangguangangguan, baik gangguan-gangguan kejiwaan maupun gangguan lingkungan. Masing-masing di antara umat Islam tentu saja bercita-cita untuk menghafal Al-Qur'an. Setiap orang juga merasakan semangat danmerasakan bahwa sebenarnya mampu menghafalnya dengan cara konsisten, menghafal surat demi surat, juz demi juz. Namun setelah itu, mulailah berbagai bisikan dan gangguan batin membuat orang tersebut malas dan semangat semakin mengendor dengan alasan banyak surat yang mirip, kata-kata yang sulit, waktu sempit, dan banyak kesibukan.

Menghafal Al-Qur'an berbeda dengan menghafal buku atau kamus. Al-Qur'an adalah kalamullah, yang akan mengangkat derajat mereka yang menghafalnya (Abdul Azis dan Abdul Rauf, 2004), oleh karena itu para penghafal Al-Qur'an perlu mengetahui hal-hal atau upaya agar mutu hafalannya tetap terjaga dengan baik.

Metode Wahdah, yakni metode menghafalkan Al-Qur'an dengan menghafal satu per satu ayat-ayat yang hendak dihafal secara berulangulang hingga hafal, kemudian melanjutkannya pada ayat-ayat berikutnya dengan cara yang sama, demikian seterusnya hingga mencapai satu halaman

Di SDN 35 Nungga Kota Bima berdasarkan pengamatan penulis melihat sudah banyak yang sudah bisa membaca Al-Qur'an ataupun menghafal surat-surat pendek pada Juz 30 namun karena kurang dan tidak adanya evaluasi maka kopetensi yang dimiliki oleh siswa tidak berkembang maka dari penulis mencoba menggali kemampuan siswa dengan menugaskan kepada siswa untuk menyetorkan hafalan mereka pada setiap pertemuan pada jam Pendidikan Agama Islam minimal dalam sekali pertemuan siswa harus menyetor hafalannya 1 surah dalam 1 kali pertemuan dan mejadikan agenda stor hafalan itu sebagai kontrak 
belajar yang akan dilakukan dalam setiap mengawali ataupun mengakhiri pelajaran.

Maka dari pengalaman itu penulis menemukan siswa-siswa yang belum bisa sama sekali ngaji sehingga menjadi perhatian khusus dalam kegiatan penyetoran surat-surat pendek, maka dari itu penulis ingin mencoba menerapkan metode wahdah dalam peningkatan hafalan siswa/siswi kelas VI dalam belajar menghafal surat-surat pendek di Juz 30 agar menjadi bekal mereka ketika masuk di SMP/MTs nantinya.

Dalam penerapan Metode wahdah ini juga menanamkan sikap ANEKA (Akuntabilitas, Nasionalisme, Etika Publik, Komitmen Mutu, dan Anti Korupsi) pada siswa/siswi baik itu dalam melaksanakan tanggung jawab terhadap tugas, rasa ingin belajar dalam meningkatkan keilmuan dalam memahami agama dan Al-Qur'an, bersama siswa sudah disepakati secara bersama maupun sikap disiplin dalam pelaksanaan kegiatan belajar dan mengajar yang dilakukan.

Berangkat dari beberapa persoalan yang dikemukan oleh penulis diatas, maka penulis beranggapan bahwa Kreativitas Guru PAI Dalam Meningkatkan Hafalan Al-Qur'an Juz 30 Melalui Metode Wahdah Pada Siswa Kelas VI SDN 35 Nungga Kota Bima sangat penting untuk di teliti dan dikaji secara ilmiah. Hal ini dilakukan agar kedepan dapat memberikan solusi bagi PAI dalam meningkatkan kualitas hafalan AlQur'an siswa melalui metode dan pedekatan yang tepat.

\section{TINJAUAN TEORITIS}

\section{Kreativitas Guru PAI}

Menurut Kamus Besar Bahasa Indonesia Kreatifitas adalah kemampuan untuk mencipta atau bersifat (mengandung) daya cipta (pekerjaan yang menghendaki kecerdasan imajinasi) 9 (Tim Penyusun Pusat Pembinaan dan Pengembangan Bahasa, 1988).

Kreativitas guru merupakan hal penting dalam pembelajaran dan bahkan dapat menjadi pintu masuk dalam upaya meningkatkan pencapaian hasil belajar siswa. perilaku pembelajaran yang di cerminkan oleh guru cenderung kurang bermakna apabila tidak diimbangi degan gagasan/ide dan prilaku pembelajaran yang kreatif. Kraetivitas baru akan muncul apabila dalam pembelajaran oleh guru didukung dengan 
pemahaman tentang makna mengajar dan belajar. Mengajar bukan hanya sekedar memberikan materi atau pun melaksanakan hal-hal tertentu, apalagi jika dikaitkan dengan pencapaian target program pengajaran. Belajar juga tidak melulu hanya mengingat apa yang di jejalkan guru/buku pelajaran kepada siswa selama kegiatan belajar mengajar. Guru bukan sekedar menitik bratkan sebagai penyampai pengetahuan dan pengalih keterampilan serta merupakan satusatunya sumber belajar, tetapi perlu dirubah menjadi pembimbing, Pembina, pengajar dan pelatihan yang berarti membelajarkan anak didik (Agung, 2010).

Menurut Rogers bahwa dalam mengembangkan kreativitasnya seorang guru perlu memperhatikan prinsip-prinsip pendidikan, yakni :

1. Guru perlu memberi kepercayaan kepada kelas agar kelas memilih belajar secara terstuktur;

2. Guru dan siswa membuat kontrak kerja;

3. Guru perlu menggunakan metode inkuiri atau belajar menemukan (discovery larning);

4. Guru pelu meggunakan metode simulasi;

5. Guru perlu mengadakan latihan kepekaan agar siswa mampu menghayati perasaan dan berpartisipasi dengan kelompok lain;

6. Guru harus bertindak sebagai fasilitator belajar; dan

7. Guru perlu menggunakan pengajaran berprogram agar tercipta peluang bagi siswa untuk timbulnya kreativitas (Agung, 2010).

Sedangkan Guru Pendidikan Agama Islam disini adalah seseorang yang mengajar dan mendidik Agama Islam dengan membimbing, menuntun, memberi tauladan dan membantu mengantarkan anak didiknya ke arah kedewasaan jasmani dan rohani. Hal ini sesuai dengan tujuan pendidikan agama yang hendak dicapai yaitu membimbing anak agar menjadi seorang muslim yang sejati, beriman, teguh, beramal sholeh dan berakhlak mulia, serta berguna bagi masyarakat, agama dan Negara (Zuhairini, 1994).

Oleh karena itu, kreativitas guru pendidikan agama Islam yaitu dengan Melalui kegiatan belajar mengajar di kelas, guru dapat memiliki kedekatan dengan siswa sehingga guru dapat dengan mudah memberikan nasehat-nasehat dengan secara tidak langsung nasehat tersebut 
merupakan penanaman nilai-nilai keagamaan dalam diri siswa. Selain itu banyak pembiasaaan dan latihan yang akan dilakukan oleh guru dalam rangka mendorong siswa supaya dapat meningkatkan kualitas bacaan dan hafalan Al-Qur'an melalui kegiatan pembelajaran yang berlangsung di sekolah.

\section{Menghafal Al-Qur'an Dengan Metode Wahdah}

Menghafal al-Qurean merupakan harta simpanan yang sangat berharga yang diperebutkan oleh orang yang bersungguh-sungguh. Hal ini karena al-Qur ${ }^{e e}$ an adalah kalam Allah yang bisa menjadi syafaee at bagi pembacanya kelak dihari kiamat. Menghafal al-Qurean keutamaankeutamaannya memiliki berbagai cara yang beragam (Muhsin, 2007).

Menurut Munjahid, ada metode yang dapat digunakan bagi para penghafal, yakni metode menghafal dengan pengulangan penuh, metode menghafal dengan tulisan, metode menghafal dengan memahami makna, metode menghafal dengan bimbingan guru. Metode yang dipaparkan Munjahid tidak jauh berbeda dengan metode yang dipaparkan oleh Ahsin yang salah satunya adalah metode wahdah (Mujahid, 2000).

Menghafalkan Al-Qur'an dengan metode wahdah adalah merupakan menghafalkan Al-Qur'an dengan cara menghafal satu persatu terhadap ayat-ayat yang hendak dihafalnya. Untuk mencapai hafalan awal, setiap ayat dapat dibaca sebanyak sepuluh kali atau dua puluh kali atau lebih, sehingga proses ini mampu membentuk pola dalam bayangannya. Setelah benar-benar hafal baru dilanjutkan pada ayat-ayat berikutnya dengan cara yang sama, demikian seterusnya hingga mencapai satu muka dengan gerak reflek pada lisannya. Setelah itu dilanjutkan membaca dan mengulang-ulang lembar tersebut hingga benar-benar lisan mampu memproduksi ayat-ayat dalam satu muka tersebut secara alami, atau reflek dan akhirnya akan membentuk hafalan yang representative (Ahasin, 1994).

Jadi,Yang dimaksud metode Wahdah, yaitu menghafal satu persatu terhadap ayat-ayat yang hendak dihafalnya. Untuk mencapai hafalan awal, setiap ayat dapat dibaca sebanyak sepuluh kali atau dua puluh kali atau lebih sehingga proses ini mampu membentuk pola dalam bayangannya. 


\section{METODOLOGI PENELITIAN}

Pendekatan yang peneliti gunakan dalam penelitian ini adalah pendekatan kualitatif. Yang di maksud penelitian kualitatif menurut Bogdan dan Tylor dalam moleong adalah prosedur penelitian yang mengahsilkan data deskriptif berupa kata-kata tertulis atau lisan dari orang-orang dan perrilkau, yang dapat di amati. Sementara Kirk dan miller dalam moleong adalah bahwa:"penelitian kualitatif adalah tradisi tertentu dalam ilmu pengetahuan sosial yang secara fundamental bergantung pada pengamatan pada manusia dalam kawaannya sendiri dan berhubungan dengan orang-orang tersebut dalam bahasnya dan dalam peristilahannya" (Margono, 2009).

Jadi, dalam penelitian ini penulis menggunakan metode deskriptif kualitatif untuk menggambarkan atau memaparkan data yang di peroleh peneliti yang berkaitan dengan Kreativitas guru pendidikan agama Islam dalam meningkatkan hafalan Al-Qur'an juz 30 melalui metode wahdah pada siswa kelas VI SDN 35 Nungga Kota Bima. Adapun metode pengumpulan data dalam penelitian adalah melalui observasi, wawancara dan dokumentasi (Suharsimi Arikunto, 2006). Metode analisis data menggunakan teknik analisis deskriptif.

\section{HASIL TEMUAN}

1. Konsultasi terkait penerapan metode wahdah dalam meningkatkan Hafalan Siswa.

\begin{tabular}{|c|c|c|}
\hline Waktu & : & $\begin{array}{l}\text { Dilaksanakan mulai Hari Rabu Tanggal } 23 \\
\text { Oktober 2019. }\end{array}$ \\
\hline Output & : & $\begin{array}{l}\text { Terlaksananya penerapan Metode sesuai dengan } \\
\text { harapan }\end{array}$ \\
\hline \multicolumn{3}{|c|}{ b. Realisasi pelaksanaan berupa waktu, output, dan penjelasan disertai evidence } \\
\hline Waktu & : & $\begin{array}{l}\text { Waktu yang dibutuhkan untuk melakukan } \\
\text { Konsutasi terkait kegiatan pertama ini yaitu } \\
\text { selama } 1 \text { hari yang dilaksanakan pada tanggal } 23 \\
\text { Oktober } 2019 \text {. }\end{array}$ \\
\hline Output & : & $\begin{array}{l}\text { - Terlaksanannya kegiatan sesuai dengan } \\
\text { target }\end{array}$ \\
\hline $\begin{array}{l}\text { Penjelasan disertai } \\
\text { evidence }\end{array}$ & : & $\begin{array}{l}\text { Dalam Penerapan Metode Wahdah untuk } \\
\text { meningkatkan Hafalan Juz 30, Narasumber perlu } \\
\text { dan penting melakukan konsultasi dan koordinasi } \\
\text { dengan Kepala sekolah dalam penerapan metode } \\
\text { Wahdah untuk meningkatkan hafalan siswa. } \\
\text { Penulis melampirkan dokumentasi berupa Foto } \\
\text { hasil konsutasi }\end{array}$ \\
\hline
\end{tabular}


2. Menyusun dan melakukan pemetaan terhadap siswa dan siswi yang sudah bisa membaca dan belum bisa membaca Al-Qur'an..

a. Target rancangan berupa waktu dan output

\begin{tabular}{|l|l|l|}
\hline Waktu & $:$ & $\begin{array}{l}\text { Dilaksanakan Pada Hari Kamis tanggal 24 } \\
\text { Oktober 2019 }\end{array}$ \\
\hline Output & $:$ & $\begin{array}{l}\text { Lebih mudah dalam melakukan penerapan } \\
\text { metode dalam meningkatkan hafalan Siswa } \\
-\begin{array}{l}\text { Agar lebih mudah dalam membagi Surah } \\
\text { sebagai bahan hafalan yang akan di pelajari } \\
\text { oleh siswa }\end{array}\end{array}$ \\
\hline
\end{tabular}

b. Realisasi Penyusunan berupa waktu, output, dan penjelasan disertai evidence

\begin{tabular}{|l|l|l|}
\hline Waktu & $:$ & $\begin{array}{l}\text { Waktu yang dibutuhkan untuk menyusun dan } \\
\text { pemetaan siswa adalah selama 1 (satu) hari } \\
\text { pada tanggal 24 Oktober 2019 }\end{array}$ \\
\hline Output & $:$ & $\begin{array}{l}\text { Terdapat 8 orang yang sudah lancar dalam } \\
\text { membaca Al-Qur'an } \\
-5 \text { orang yang bacaannya masih terbata-bata dan } \\
- \text { 4 orang yang belum bisa membaca Al-Qur'an }\end{array}$ \\
\hline $\begin{array}{l}\text { Penjelasan disertai } \\
\text { evidence }\end{array}$ & $: \begin{array}{l}\text { Penyusunan dan pemetaan siswa yang sudah dan } \\
\text { lancar, yang masih terbata-bata dan belum bisa } \\
\text { membaca Al-Qur'an sangat penting agar lebih } \\
\text { mudah memberikan surah-surah di juz 30 untuk } \\
\text { mereka pelajari sesuai kemampuan mereka } \\
\text { masing-masing, dokumentasi berupa Foto } \\
\text { terlampir }\end{array}$ \\
\hline
\end{tabular}

3. Pemetaan dan penerapan metode untuk meningkatkan hafalan siswa pada juz 30 sebagai bahan pembelajaran sesuai kemampuan bacaan siswa.

a. Target rancangan berupa waktu dan output

\begin{tabular}{|l|l|l|}
\hline Waktu & $:$ & Dilaksanakan mulai tanggal 26 Oktober 2019. \\
\hline Output & $:$ & $\begin{array}{l}\text { - Siswa akan lebih mudah mempelajari surat } \\
\text { yang sesuai kemampuan bacaan mereka }\end{array}$ \\
\hline
\end{tabular}

b. Realisasi pelaksanaan berupa waktu, output, dan penjelasan disertai evidence

\begin{tabular}{|l|l|l|}
\hline Waktu & $:$ & $\begin{array}{l}\text { Waktu yang dibutuhkan untuk menyelesaikan } \\
\text { rancangan kegiatan ini yaitu selama 7 hari yang } \\
\text { dimulai dari tanggal 11 hingga 18 Mei 2019, }\end{array}$ \\
\hline
\end{tabular}




\begin{tabular}{|c|c|c|}
\hline & & sesuai dengan target. \\
\hline Output & $:$ & $\begin{array}{l}\text { - Siswa Yang Sudah Lancar Akan Mempelajari } \\
\text { Surat, Al-Adziyat, Al-Zaljalah, Al-Bayinat, Al- } \\
\text { Alaq, At-Tin, Ad-Dhuha, Al-Lail, As-Syams, } \\
\text { Al-Balad, Al-Fajr, Al-Gosiyah Dan Al-A'la } \\
\text { - Siswa Yang Bacaan Masih Terbata-Bata, Al- } \\
\text { Kafirun, Al-Fiil, Al-Qurais, Al-Ma'un, Al- } \\
\text { Ashr, At-Takasur, Al-M-Humajah, Al-Qoriah, } \\
\text { Al-Qodar Dan Al-Inshirad } \\
\text { - Siswa yang belum bisa Al-Falaq, An-Nas, Al- } \\
\text { Ikhlas, Al-Lahab, An-Nars dan Al-Kausar }\end{array}$ \\
\hline $\begin{array}{l}\text { Penjelasan disertai } \\
\text { evidence }\end{array}$ & $:$ & $\begin{array}{l}\text { Pemetaan surat-surat yang akan dipelajariu oleh } \\
\text { siswa ini sangat penting agar kita tidak salah } \\
\text { dalam memberikan surat poada juz } 30 \text {, } \\
\text { contohnya siswa yang belum bisa mmembaca } \\
\text { kita memberikan surat-surat yang panjang, maka } \\
\text { seperti itu akan susah maka dengan pemetaan ini } \\
\text { memudahkan untuk memberikan surat-surat pada } \\
\text { juz } 30 \text { pada siswa sesuai kadar bacaan } \\
\text { mereka,Pertama Pesiswa yang sudah lancar } \\
\text { mendapat tugas untuk menghafal surat Al- } \\
\text { Zaljalah, Kedua. Siswa yang bacaannya terbata- } \\
\text { bata menghafal surat Al-Qodar. Ketiga. Siswa } \\
\text { yang belum bisa membaca Al-qur'an menghafal } \\
\text { surat Al-Lahab. dokumendasi berupa foto } \\
\text { terlampir. }\end{array}$ \\
\hline
\end{tabular}

4. Penguatan hafalan siswa sesuai surat yang di sudah dibagikan.

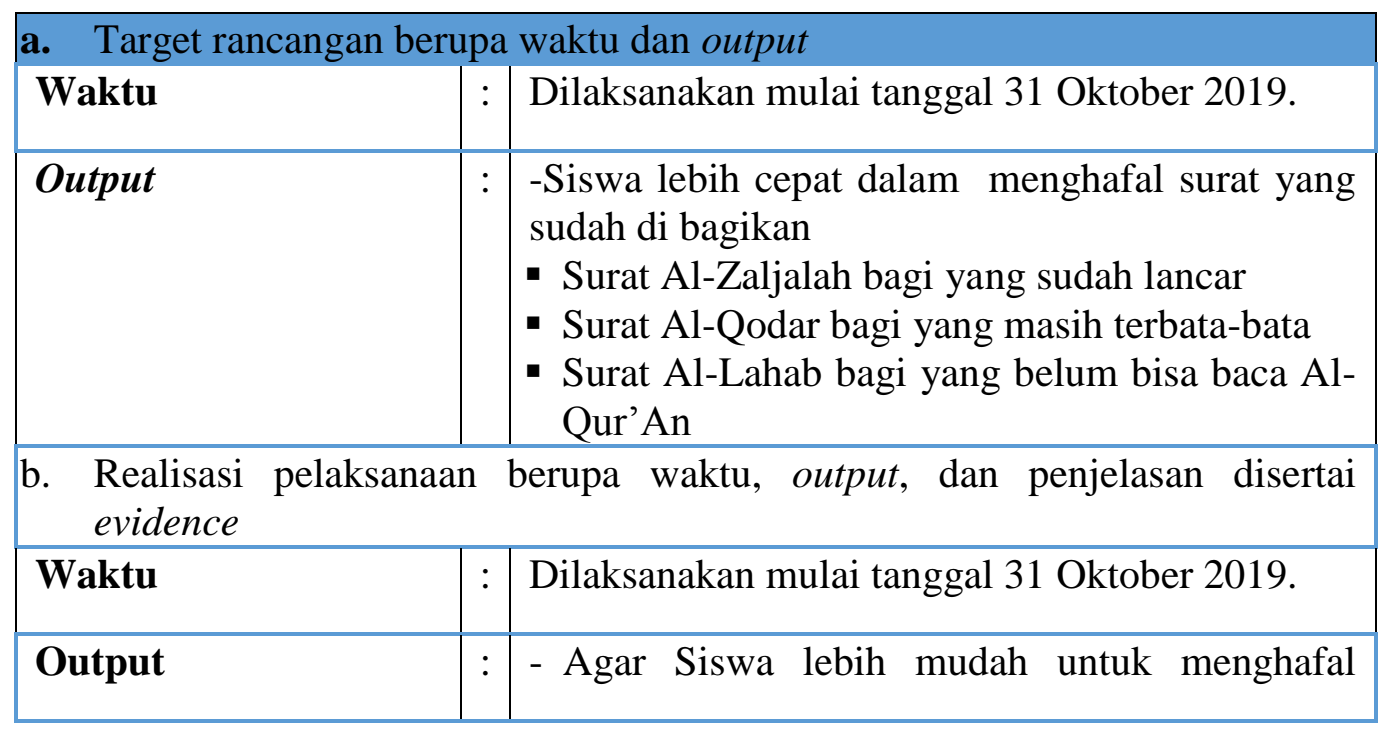




\begin{tabular}{|l|l|l|}
\hline & $\begin{array}{l}\text { surat yang sudah dibagikan sesuai dengan } \\
\text { kapasitas bacaan siswa masing- } \\
\text { - Surat Al-Zaljalah bagi yang sudah lancar } \\
\text { - Surat Al-Qodar bagi yang masih terbata-bata } \\
\text { - Surat Al-Lahab bagi yang belum bisa baca } \\
\text { Al-Qur'An }\end{array}$ \\
\hline $\begin{array}{l}\text { Penjelasan disertai } \\
\text { evidence }\end{array}$ & $: \begin{array}{l}\text { Penguatan hafalan adalah merupakan langkah } \\
\text { untuk mengecek apakah hafalan siswa sudah } \\
\text { sesuai atau belum, agar dapat di lakukan } \\
\text { penguatan terhadap surat-surat yang belum siswa } \\
\text { bisa hafal. Dokumentasi kegiatan berupa vidio } \\
\text { dan foto terlampir }\end{array}$ \\
\hline
\end{tabular}

5. Penyetoran hafalan Siswa.

\begin{tabular}{|l|l|l|}
\hline a. Target rancangan berupa waktu dan output \\
\hline Waktu & $:$ & Dilaksanakan pada tanggal 02 Noemberv 2019. \\
\hline Output & $:$ & $\begin{array}{l}\text {-Siswa dapat menghafal surat-surat yang sudah } \\
\text { di bagikan sesuai kadar bacaan siswa. } \\
\text { - Surat Al-Zaljalah bagi yang sudah lancar } \\
\text { - Surat Al-Qodar bagi yang masih terbata-bata } \\
\text { - Surat Al-Lahab bagi yang belum bisa baca } \\
\text { Al-Qur'An }\end{array}$ \\
\hline $\begin{array}{l}\text { Realisasi pelaksanaan } \\
\text { evidence }\end{array}$ & $:$ & $\begin{array}{l}\text { Waktu yang dibutuhkan untuk menyelesaikan } \\
\text { berupa waktu, output, dan penjelasan disertai } \\
\text { mulai pada tanggal 26 Oktober s/d 02 November } \\
\text { 2019.. }\end{array}$ \\
\hline $\begin{array}{l}\text { Waktu } \\
\text { Output }\end{array}$ & $: \begin{array}{l}\text { Siswadapat menyetor hafalan yang sudah } \\
\text { mereka pelajari dengan lancar }\end{array}$ \\
\hline evidence & $:$ & $\begin{array}{l}\text { Setoran hafalan adalah merupakan tidak lanjut } \\
\text { dari kegiatan sebelumnya untuk memastikan } \\
\text { apakah siswa benar-benar sudah lancar atau } \\
\text { belum dalam menghafal surat-surat yang mereka } \\
\text { pelajari masing-masing dengan menggunakan } \\
\text { metode murojaah. Dokumentasi baik foto dan } \\
\text { kegiatan terlampir. }\end{array}$ \\
\hline
\end{tabular}


6. Pembagian surah untuk di hafal surah kedua.

\begin{tabular}{|l|l|l|}
\hline \multicolumn{2}{|l|}{ a. Target rancangan berupa waktu dan output } \\
\hline Waktu & $:$ & Dilaksanakan Pada tanggal 07 November 2019. \\
\hline Output & $:$ & $\begin{array}{l}\text { Siswa lebih cepat menghafal surat-surat yang di } \\
\text { bagi }\end{array}$ \\
\hline $\begin{array}{l}\text { b. Realisasi pelaksanaan } \\
\text { evidence }\end{array}$ & $:$ & $\begin{array}{l}\text { Waktu yang dibutuhkan untuk menyelesaikan } \\
\text { bancangan kegiatan ini yaitu selama 1 hari yang } \\
\text { dilaksanakan pada tanggal 07 November 2019, }\end{array}$ \\
\hline Waktu & $:$ & $\begin{array}{l}\text { Siswa lebih awal mempelajari surat-surat yang } \\
\text { dibagikan. } \\
\text {-Surat Al-dhuha } \\
\text {-Surat Al-Adiyaat } \\
\text {-Surat At-Takasur } \\
\text {-Surat Al-Humajah } \\
\text {-Surat Al-Fiil } \\
\text {-Surat Al-Lahab }\end{array}$ \\
\hline $\begin{array}{l}\text { Penjelasan disertai } \\
\text { evidence }\end{array}$ & $:$ & $\begin{array}{l}\text { Kegiatan ini adalah lanjutan dari kegiatan } \\
\text { hafalan pekan lalu setelah mereka sudah bisa } \\
\text { membaca dan menghafal surat-surat yang lain } \\
\text { Dokumentasi dilampirkan pada lampiran. }\end{array}$ \\
\hline
\end{tabular}

7. Penguatan hafalan siswa

a. Target rancangan berupa waktu dan output

\begin{tabular}{|l|l|l|}
\hline Waktu & $:$ & $\begin{array}{l}\text { Dilaksanakan tanggal tanggal 16 November } \\
2019\end{array}$ \\
\hline Output & $:$ & - Mengetahui kadar bacaan siswa \\
\hline
\end{tabular}

b. Realisasi pelaksanaan berupa waktu, output, dan penjelasan disertai evidence

\begin{tabular}{|l|l|l|}
\hline Waktu & $:$ & $\begin{array}{l}\text { Waktu yang dibutuhkan untuk menyelesaikan } \\
\text { Penguatan ini yaitu selama 2 hari yang dimulai } \\
\text { dari tanggal 16 November 2019, sesuai dengan } \\
\text { target. }\end{array}$ \\
\hline Output & $:$ & $\begin{array}{l}\text { Dapat memahami tingkat kelancaran hafalan } \\
\text { siswa } \\
\text { Siswa dapat menghafal surat-surat yang }\end{array}$ \\
\hline
\end{tabular}




\begin{tabular}{|l|l|}
\hline & dipejari. \\
\hline $\begin{array}{l}\text { Penjelasan disertai } \\
\text { evidence }\end{array}$ & $: \begin{array}{l}\text { Penguatan hafalan siswa dilakukan guna } \\
\text { memberikan menginformasikan terhadap siswa } \\
\text { terhadap surat-surat yang akan dipejari baik di } \\
\text { sekolah maupun dirumah, maka perlu dan } \\
\text { penting guru untuk melakukannya agar dapat } \\
\text { mengetahui sampai dimana hafalan siswa } \\
\text { terhadap surat yang dihafal untuk mereka setor } \\
\text { pekan depan. Dokumentasi berupa foto dan vidio } \\
\text { terlampir. }\end{array}$ \\
\hline
\end{tabular}

8. Penyetoran Hafalan

\begin{tabular}{|l|l|l|}
\hline b. Target rancangan berupa waktu dan output \\
\hline Waktu & $:$ & Dilaksanakan mulai tanggal 27 November 2019. \\
\hline Output & $:$ & $\begin{array}{l}\bullet \text { Siswa dapat menghafal surat yang sudah di } \\
\text { bagikan } \\
\bullet \text { Siswa dapat mengetahui nama suratyang dihafal }\end{array}$ \\
\hline
\end{tabular}

c. Realisasi pelaksanaan berupa waktu, output, dan penjelasan disertai evidence

\begin{tabular}{|l|l|l|}
\hline Waktu & $:$ & $\begin{array}{l}\text { Waktu yang dibutuhkan untuk menyelesaikan } \\
\text { Penyetoran Hafalan yaitu selama 1 hari yang } \\
\text { Laksanakan pada tanggal 27November 2019, } \\
\text { sesuai dengan target. }\end{array}$ \\
\hline Output & $: \begin{array}{l}\bullet \text { Siswa yang sudah lancar dapat meghafal surat } \\
\text { Al-Adziyat dan Ad-dhuha } \\
\text { - Siswa yang terbata-bata dapat mengahafal surat } \\
\text { Al-Qurais dan Al-Fiil } \\
\text { - Siswa yang belum bisa membaca dapoat } \\
\text { menghafal surat Al-Lahab }\end{array}$ \\
\hline $\begin{array}{l}\text { Penjelasan disertai } \\
\text { evidence }\end{array}$ & $: \begin{array}{l}\text { Pelaksanaan kegiatan penyetoran Hafalan adalah } \\
\text { untuk mengetahui sejauh mana siswa dan siswi } \\
\text { dapatmenbghafal surat dijuz 30 yang sudah } \\
\text { dibagikan, dan sebelum siswa mulai guru } \\
\text { melakukan pengecekan terhadap hafalan siswa di } \\
\text { tiap-tiap kelompok, dokumentasi kegiatan } \\
\text { terlampir. }\end{array}$ \\
\hline
\end{tabular}

Tabel 5. Hasil Aktualisasi 


\section{Kendala dan Antisipasi}

Dalam pelaksanaan aktualisasi ini terdapat beberapa kendala yang dapat menjadi hambatan, adapun beberapa kendala tersebut sebagai berikut:

\begin{tabular}{|c|c|c|c|}
\hline NO. & KEGIATAN & KENDALA & ANTISIPASI \\
\hline 1. & $\begin{array}{l}\text { Melakukan pemetaan } \\
\text { surat-surat di Juz } 30 \\
\text { untuk di hafal oleh } \\
\text { Peserta Didik. }\end{array}$ & $\begin{array}{l}\text { Sudah banyaknya } \\
\text { setoran hafalan siswa } \\
\text { sebelum penerapana } \\
\text { metode wahdah ini } \\
\text { sehingga pemetaan } \\
\text { atau pembagian surat } \\
\text { yang akan di hafal bisa } \\
\text { berbeda setiap siswa. }\end{array}$ & $\begin{array}{l}\text { Siswa yang sudah } \\
\text { menghafal atau menyetor } \\
\text { surat yang akan di pelajari } \\
\text { bersama akan diberkan } \\
\text { tugas untuk mempelajari } \\
\text { atau menghafal surat-surat } \\
\text { yang lain. }\end{array}$ \\
\hline 2. & $\begin{array}{l}\text { Memisahkan siswa yang } \\
\text { sudah bisa membaca } \\
\text { dengan lancar, Siswa } \\
\text { yang masih terbata-bata } \\
\text { dan yang belum bisa } \\
\text { sama sekali membaca Al- } \\
\text { Qur'an }\end{array}$ & $\begin{array}{l}\text { Siswa yang belum bisa } \\
\text { membaca Al-Quran } \\
\text { memang sedikit susah } \\
\text { untuk menghafal } \\
\text { karena apa yang sudah } \\
\text { di pelajari pekan ini } \\
\text { dan jika di ulangi } \\
\text { selang beberapa menit } \\
\text { mereka melupakan } \\
\text { apa yang sudah } \\
\text { mereka hafal apalagi } \\
\text { harus menunggu satu } \\
\text { pekan untuk mereka } \\
\text { menyetorkan } \\
\text { hafalannya }\end{array}$ & $\begin{array}{l}\text { Memberikan durasi waktu } \\
\text { yang lebih dari kelomok } \\
\text { lain dan mengajar } \\
\text { menghafal surat-surat } \\
\text { yang di hafal perkata } \\
\text { tidak seperti kelompok } \\
\text { lain, serta terkadang } \\
\text { meminta siswa yang } \\
\text { sudah lancar untuk } \\
\text { mendampingi mereka. }\end{array}$ \\
\hline 3. & $\begin{array}{l}\text { Menguji hafalan siswa } \\
\text { sesuai dengan surat-surat } \\
\text { pendek juz } 30 \text { yang } \\
\text { sudah di pelajari. }\end{array}$ & $\begin{array}{l}\text { Saat melakuka ujian } \\
\text { hafalan siswa yang } \\
\text { menjadi kendala } \\
\text { adalah jikat dalam satu } \\
\text { kelompok mereka } \\
\text { menghafal lebih dari } \\
\text { satu surat yang } \\
\text { mereka hafal dan ini } \\
\text { akan memakan waktu } \\
\text { lama ketika melakukan } \\
\text { murajaah bersama- } \\
\text { sama. }\end{array}$ & $\begin{array}{l}\text { Setiap siswa yang belum } \\
\text { lancar akan disuruh bejar } \\
\text { lagi sampai bisa dan jika } \\
\text { waktur tidak } \\
\text { memungkinkan akan } \\
\text { menyetor hafalan yang } \\
\text { belum mereka setor di } \\
\text { pertemuan selanjutnya. }\end{array}$ \\
\hline
\end{tabular}


4. Evaluasi

Tabel 1. 6. Kendala dan Antisipasi

\section{SIMPULAN}

Sebagai guru PAI harus mempunyai kreativitas dalam mengelola pembelajaran walaupun ada kesamaan dalam metode pengajarannya. Semua ini bertujuan untuk meningkatkan kualitas hafalan Al-Qur'an pada juz 30 di SDN 35 Nunggi Kota Bima. Setiap guru PAI di SDN 35 Nunggi Kota Bima diharuskan terus berupaya meningkatkan kreativitasnya baik dari penggunaan metode pembelajaran, pemanfaatan sarana dan prasarana yang ada serta menggunakan media yang tepat untuk menunjang tercapainya tujuan pembelajaran.

Penerapan metode wahdah yang dilakukan oleh guru PAI di SDN 35 Nungga Kota adalah dengan cara mempersiapkan al-Qurean pojok yang terdiri dari lima belas baris dalam satu halamannya dan setiap halaman diakhiri oleh ayat kemudian membaca satu persatu ayat-ayat yang hendak dihafalnya, setiap ayat yang hendak dihafalkan dibaca berulang-ulang sepuluh sampai dua puluh kali hingga membentuk pola dalam bayangannya.

\section{DAFTAR PUSTAKA}

Abdul Azis dan Abdul Rauf 2004. Kiat Sukses menjadi Hafidz Qur'an Da'iyah, Bandung, Syaamil Cipta Media.

Abdurrab Nawabudin. 1991. Teknik Menghafal Al-Qur'an, Bandung, Sinar Baru.

Agung. 2010. Meningkatkan Kreativitas Pembelajaran Bagi Guru, Jakarta, Bestari Buana Murni.

Ahsin W. 2000. Bimbingan Praktis Menghafal Al-Qur'an, Jakarta, Bumi Aksara.

Departemen Agama RI. 2006. Al-Qur'an dan Terjemahnya, Jakarta:Toha Putra.

Khalid bin Abdul Karim Al-Lahim. 2008. Mengapa Saya Menghafal Al-Qur'an, Surakarta, Daar An-Naba.

Margono. 2009. Metodologi Penelitian Pendidikan : Komponen MKDK, Jakarta, Rineka Cipta.

Muhsin, 2007. Kunci-Kunci Surga, Solo, Aqwam.

Mujahid. 2000. Strategi Menghafal Al-Qurean 10 Bulan Khatam, Yogyakarta, Idea Press.

Raghib As-Sirjani. 2007. Cara Cerdas Hafal Al-Qur'an, Solo, Aqwam.

Suharsimi Arikunto. 2006. Prosedur Penelitian Suatu Pendekatan Praktik, Jakarta, Rineka Cipta. 
Tim Penyusun Pusat Pembinaan dan Pengembangan Bahasa. 1988. Kamus Besar Bahasa Indonesia, Jakarta, Balai Pustaka.

Zuhairini. 1994. Sejarah Pendidikan Islam, Jakarta: Aksara. 